\title{
CMA okays private health care for waiting patients
}

Published at www.cmaj.ca on Aug. 18, 2005.

Citing the recent Supreme Court of Canada ruling and concerns about lengthy wait times, the Canadian Medical Association has endorsed private health insurance and private-sector health services for patients who don't get timely treatment through the public system.

Following a heated debate on Aug. 17 at CMA General Council in Edmonton, $64 \%$ of delegates (122) voted in favour of the motion and 35\% (67 delegates) opposed it.

Dr. Albert Schumacher, CMA's outgoing president, said the move "totally reinforced" the June 9 Supreme Court judgment that struck down a ban on private health insurance in Quebec. The court later agreed to delay implementing its landmark ruling in the Chaoulli case until June 2006.

"We can't ignore the Supreme Court," Schumacher said.

The president of the Quebec Medical Association proposed the motion to support private health insurance. "We have to provide all possible solutions so we have timely access to health care," said Dr. Robert Ouellet. He conceded, however, that private access was not the only solution to lengthy wait times.

Nor is this CMA's sole approach to the problem of lengthy wait times. Earlier at the general council meeting, delegates decided to prepare a "blueprint" on the private-public split by February 2006. The CMA will also ask Canadian governments to introduce and implement national wait times developed by the Health Canada-funded Wait Time Alliance in its final report. Delegates also supported a separate motion saying that Canadians who can't get timely access in Canada should be allowed to go elsewhere, in Canada or internationally, to get the treatment they need, and be reimbursed by government.

The CMA's support of pri- vate health insurance brought an immediate negative reaction from groups representing bothpatients and professionals.

The Canadian Association of Internes and Residents (CAIR) was "disappointed" by the vote. "We want timely access to care for all patients, not just those who can afford it," said Dr. Ben Hoyt, president of the 7500member association.

Hoyt said the motion belies principles CMA had endorsed a day earlier (Aug. 16) when it passed a motion stating that access to health care must be based on need, not ability to pay. "The Supreme Court has given us one year to fix ... the system. Let's look at all the options."

Friends of Medicare, an advocacy federation of patient, union and professional groups, said CMA has "abdicated its responsibility as the "parliament of medicine'." That abdication will cost physicians the "trust of Canadians," said Coordinator Harvey Voogd.

Although the CMA endorsed private insurance, federal Health Minister Ujjal Dosanjh clearly did not. Addressing the meeting Aug. 15, he said privatization is not a "panacea" and warned that it could create inequitable access. The Supreme Court decision does not require the creation of a parallel private health care system, Dosanjh insisted, saying Ottawa is committed to improving public health care.

Conservative health critic Steven Fletcher said "We should be open to a publicly funded system that allows privately funded options."

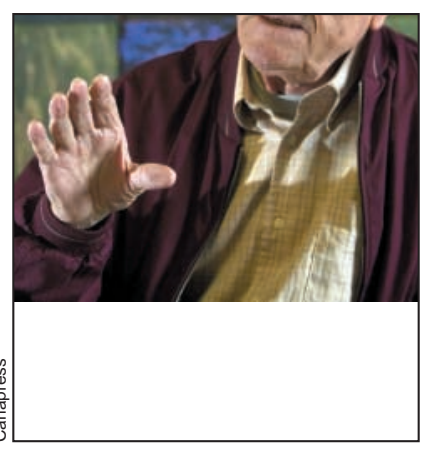

Quebec patient George Zeliotis (above) and Dr. Jacques Chaoulli argued all the way to the Supreme Court for the right to private insurance.

The motion supporting private insurance came during an unscheduled second session on the public-private interface Aug. 17. Due to insufficient time, 10 motions were still referred to CMA's Board of Directors for action. - Barbara Sibbald, CMAJ

\section{ACCESSIBILITY}

\section{Questions raised about private insurance}

Published at www.cmaj.ca on Aug. 17, 2005.

The CMA's decision to open the door to private health insurance raises new questions about accessibility (see article above).

Health insurance isn't readily available to people with pre-existing conditions, acknowledged QMA President Dr. Robert Ouellet, who proposed the CMA motion regarding private funding. This means Canadians would have to buy insurance when they are healthy on the assumption that they won't have timely access to care if they need it.

Furthermore, an August CMA poll found that 58\% of physicians feel their patients either don't qualify for, or can't afford, private health insurance.

CMA President Dr. Ruth Collins-Nakai said earlier this summer that Canada needs to reform the insurance industry to ensure widespread accessibility.

C. The motion supporting private insurance "is not a solution that is going to help our patients," said Ottawa emergency physician Atul Kapur. "It's a solution that will help in-

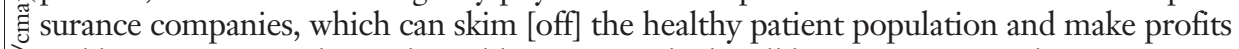
and leave everyone else to the public system, which will be in even worse shape."

Other delegates disagreed. "We're saying, 'Simply give patients another option to $\stackrel{-}{*}$ alleviate their suffering,", said Dr. Larry Erlick of North York, Ont. "The reality is that § governments are failing my patients." - Barbara Sibbald, CMAJ 